Review article

\title{
Hexachlorobenzene sources, levels and human exposure in the environment of China
}

\author{
Guang Wang ${ }^{\mathrm{a}, \mathrm{b}}$, Yonglong Lu ${ }^{\mathrm{a}, \mathrm{b}, *}$, Jingyi Han ${ }^{\mathrm{a}, \mathrm{c}}$, Wei Luo ${ }^{\mathrm{a}}$, Yajuan Shi ${ }^{\mathrm{a}}$, Tieyu Wang ${ }^{\mathrm{a}}$, Yamei Sun ${ }^{\mathrm{a}, \mathrm{b}}$ \\ a Research Center for Eco-Environmental Sciences, Chinese Academy of Sciences, Beijing, 100085, China \\ b Graduate School of Chinese Academy of Sciences, Beijing, 100039, China \\ ' Environmental Policy Group, Wageningen University, 6706, KN, Wageningen, the Netherlands
}

\section{A R T I C L E I N F O}

\section{Article history:}

Received 16 January 2009

Accepted 26 August 2009

Available online 8 October 2009

\section{Keywords:}

HCB

Pollution

Sources

China

Human exposure

\begin{abstract}
A B S T R A C T
This article summarizes the published scientific data on sources, levels and human exposure of hexachlorobenzene (HCB) in China. Potential sources of unintended HCB emission were assessed by production information, emission factors and environmental policies. HCB was observed in various environmental compartments in China. HCB levels increased from South China to North China in most of environmental compartments (air, soil and mussel). Some hotspots were identified near the factories producing and using HCB. In terms of spatial distribution, $\mathrm{HCB}$ concentrations in air and shellish showed much variation, which indicated some primary emission sources in China. HCB levels in air and human milk in China were relatively higher than those in other countries, but HCB levels in other compartments were similar to those in Europe and other countries in Eastern Asia. In the limited studies on temporal trends of HCB levels in China, HCB concentrations in air, sediment, fish and human milk did not show a consistent downward trend. Although HCB levels in food and human milk does not pose a health risk in China at present, long-term exposure to HCB should not be overlooked.
\end{abstract}

(c) 2009 Elsevier Ltd. All rights reserved.

\section{Contents}

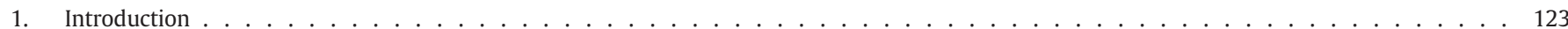

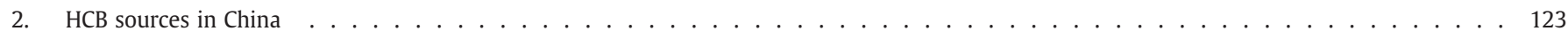

2.1. Direct production and use of $\mathrm{HCB}$ in China . . . . . . . . . . . . . . . . . . . . . . . . . . 123

2.2. Unintended $\mathrm{HCB}$ emissions in China . . . . . . . . . . . . . . . . . . . . . . . . . . . . . . . 123

2.2.1. Pesticides with $\mathrm{HCB}$ impurity . . . . . . . . . . . . . . . . . . . . . . . . . . . . . . . . 123

2.2.2. Manufacturing emissions . . . . . . . . . . . . . . . . . . . . . . . . . . . . . 124

2.2.3. Metals industry and combustion processes . . . . . . . . . . . . . . . . . . . . . . . . . . 124

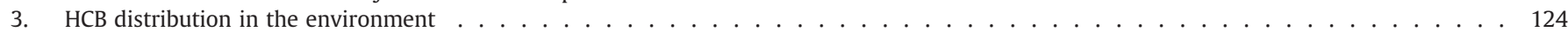

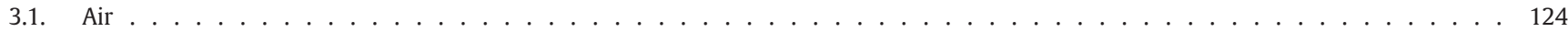

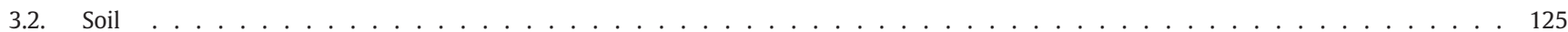

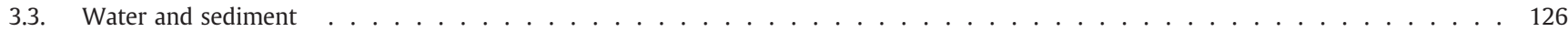

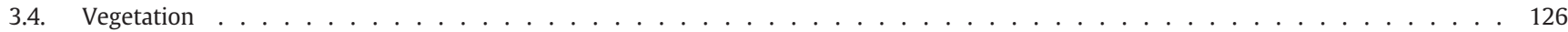

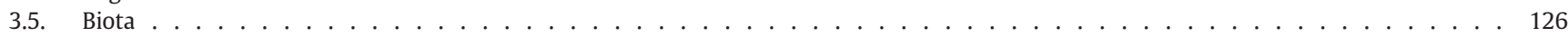

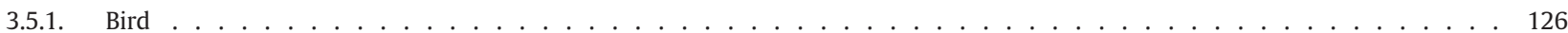

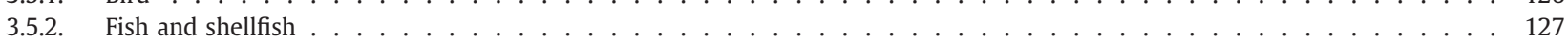

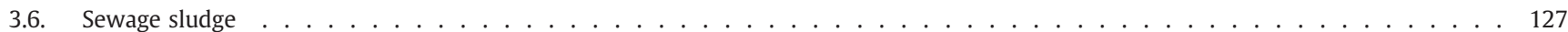

4. Human exposure . . . . . . . . . . . . . . . . . . . . . . . . . . . . . . . . . . . . . 127

4.1. HCB residues in food and human exposure . . . . . . . . . . . . . . . . . . . . . . . . . 127

4.2. HCB residues in human milk and tissue . . . . . . . . . . . . . . . . . . . . . . . . . . . . . . . . . . . . . . . .

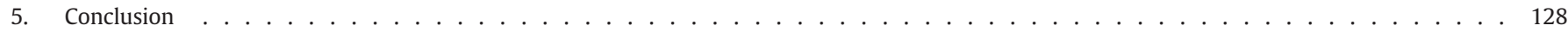

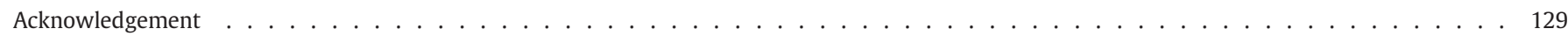

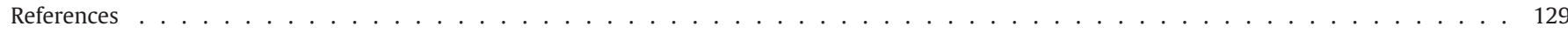

* Corresponding author. Present address: State Key Laboratory of Urban and Regional Ecology, Research Center for Eco-Environmental Sciences, Chinese Academy of Sciences, P.O. Box 2871, Beijing 100085, China. Tel.: +86 10 62849466; fax: +86 1062918177.

E-mail address: yllu@rcees.ac.cn (Y. Lu). 


\section{Introduction}

Hexachlorobenzene (HCB) is one of the twelve persistent organic pollutants (POPs) listed under the Stockholm Convention, and has characteristics of persistence, bioaccumulation, toxicity, and long-range environment transport. HCB is extremely stable, globally distributed, and to be a most persistent POP (Meijer et al., 2003a).

HCB in the environmental compartments is not only from its industrial and agricultural application, but also produced as trace contaminant in several pesticides and as an unintended byproduct during the industrial manufacture and combustion processes (Bailey, 2001). HCB was first introduced in 1933 as a fungicide. Agricultural use of HCB dominated its emissions during the 1950s and 1960s (Courtney, 1979). Although HCB production and use has been ceased before 2000 in most countries, $\mathrm{HCB}$ is still being released to the environment as an unintended byproduct in chemical processes, incomplete combustion and an impurity in pesticides. Current emissions are estimated to be $70 \%-95 \%$ lower than that in 1970 because of the banning of HCB for agricultural use (Barber et al., 2005).

HCB has been observed all over the world in air, soil, water, sediment, biota and human tissues. The atmospheric concentrations are now fairly uniform, varying by less than an order of magnitude at background sites. However, highest HCB air concentrations were still found in historical source regions, indicating that there are some ongoing primary or secondary emissions (Jaward et al., 2005). HCB concentrations in background soils were strongly influenced by source region and soil organic matter content (Meijer et al., 2003a; Valle et al., 2005). HCB levels in biota and human were affected by regional and local historical HCB emissions. Levels of HCB in the environment have dropped substantially in the past 20 years as shown by many studies (Braune, 2007; Bustnes et al., 2007; Kannan et al., 1992), which shows the consistent decrease of $\mathrm{HCB}$ emissions and HCB is being degraded in the environment. HCB has been reported in tissues of polar bears and penguins from the Arctic and the Antarctic, there are no consistent downward trend of $\mathrm{HCB}$ in certain polar locations (Corsolini et al., 2002; Kannan et al., 2005).

Although emission and distribution of HCB have been well documented at global scale, information about that in China is limited. There are many studies on HCB concentrations in various environmental compartments in China, but only a few focused on the countrywide distribution of HCB. Moreover, most of the studies on HCB levels were scattered in the articles about organochlorine pesticides (OCPs) and only listed the data of concentrations with few discussions about the relations between the sources and levels of HCB. Furthermore, some results were partial because of insufficient information about HCB emissions and distribution in China, which may lead to misunderstanding of $\mathrm{HCB}$ pollution status in China. Therefore, the objectives of this study are to assess all potential sources of HCB in China, to discuss spatial distribution and temporal trends of HCB levels, to find relations between the sources and levels of $\mathrm{HCB}$, to indicate human exposure to $\mathrm{HCB}$, and to give recommendations for further studies through the overview of published scientific data.

\section{HCB sources in China}

\subsection{Direct production and use of $H C B$ in China}

HCB has never been used directly as a pesticide in China, but has been used to produce pentachlorophenol (PCP) and pentachlorophenol-Na (PCP-Na), reagent and fireworks (Wei et al., 2007b). Hexachlorocycloheaxane $(\mathrm{HCH})$ was used to produce lindane and HCB in China $(\mathrm{HCH}$ is thermally dehydrohalogenated to trichlorobenzene and then chlorinated to produce HCB which is treated with $\mathrm{NaOH}$ to produce PCP and PCP-Na). China began to produce HCB in 1958 , and in total there were $6 \mathrm{HCB}$ production enterprises. Due to control over $\mathrm{HCH}$ production and usage after 1983, the production of $\mathrm{HCB}$ has been reduced drastically. After 1983, there is only one enterprise in Tianjin continuing with HCB production in the whole country. Cumulative production of HCB after 1988 was 79,278 tons, of which 78,323 tons were used to produce Na-PCP and PCP, accounting for $98.8 \%$ of the total production. The rest was mainly used to produce fireworks. Data on HCB production in China from 1988 to 2003 are listed in Fig. 1. Production was reduced year by year after 2000 and completely stopped in 2004. As a part of China's National Implementation Plan (NIP) for Stockholm Convention, the government prohibited the production and use of HCB in 2009 (SEPA, 2007).

\subsection{Unintended $H C B$ emissions in China}

There are no unintended HCB emission inventories in China at present, and the literature about unintended HCB emissions from potential sources is limited. In this section, we try to collect and summarize the available information on unintended HCB sources in China and assess emissions and trends of all potential HCB sources.

\subsubsection{Pesticides with HCB impurity}

HCB was reported to be a trace contaminant in several pesticides containing chlorine (Benazon, 1999; Pacyna et al., 2003). In the 1990 HCB inventories of the US, the following pesticides contained HCB as a contaminant: atrazine, simazine, picloram, pentachloronitrobenzene (PCNB), chlorothalonil, dimethyl tetrachloroterephthalate (DCPA), lindane, technical HCH, PCP and PCP-Na (USEPA, 1998). In China, production and use of technical $\mathrm{HCH}$ and lindane were prohibited in 1983 and 2000 respectively (Wang et al., 2005a). PCP was produced until 1995 (Fig. 2) and registered as wood preserving agent by the Ministry of Agriculture of China. PCP-Na was produced and used as wood preserving agent and molluscicide from 1958 to 2003 (Fig. 2). PCNB is not allowed for crops. Other pesticides containing HCB are produced and used widely in China, of which only chlorothalonil has been given National Standard for HCB impurity with permissible value of $0.04 \%$ (GB-9551-1999). HCB concentration in picloram in China was $1.15 \mathrm{mg} / \mathrm{kg}$ (Lu, 2007), much lower than that $(50 \mathrm{mg} / \mathrm{kg}$ ) reported in the US 1990 emission inventories. HCB concentration in chlorothalonil was $42.2 \mathrm{mg} / \mathrm{kg}$ in China (Wang et al., 2005b), similar to the data $(40 \mathrm{mg} / \mathrm{kg})$ reported in US 1990 emission inventories. Pesticide application may be an important source of HCB in the environment because of widespread use of pesticides and the lack of strict regulations on HCB impurity in pesticides in China.

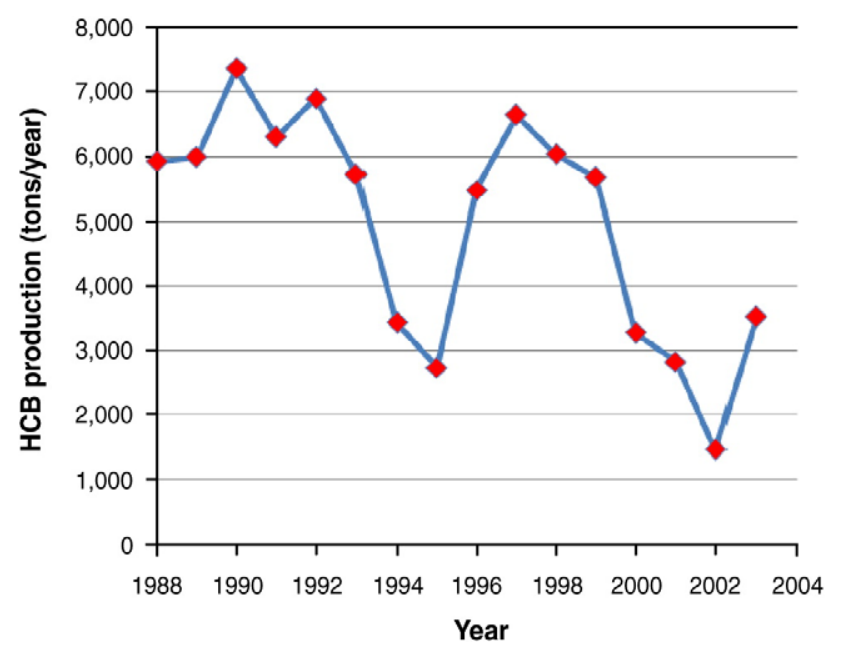

Fig. 1. HCB production from 1988 to 2003 in China ${ }^{\mathrm{a}}$ (SEPA, 2007). ${ }^{\mathrm{a}}$ No data about HCB production available before 1988 . 


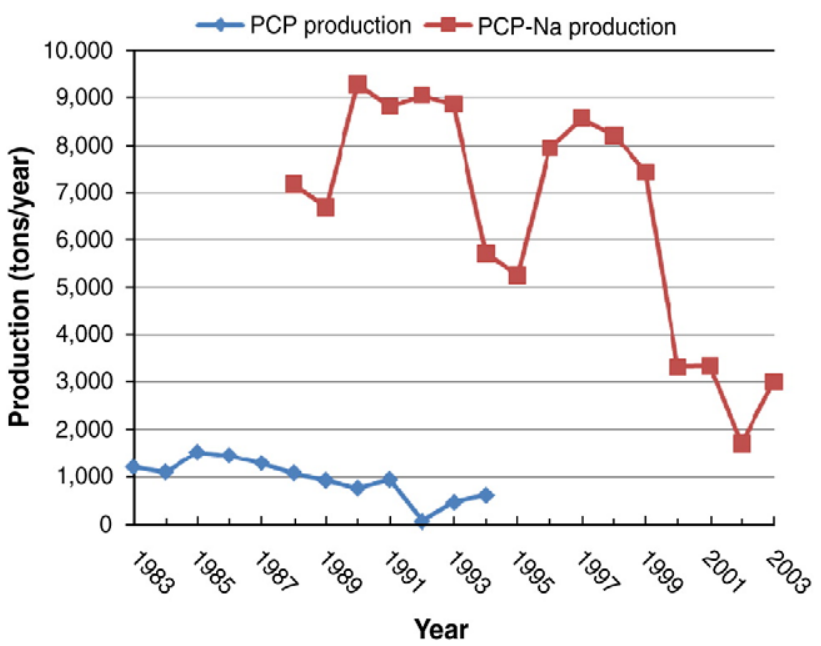

Fig. 2. $P C P$ and $P C P-N a$ production in China ${ }^{a}, b(S E P A, 2007)$. ${ }^{a}$ No data about PCP production

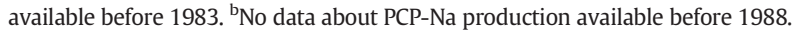

\subsubsection{Manufacturing emissions}

Many studies revealed that HCB production and use in some chemical plants caused elevated HCB levels in the surrounding environment (Barber et al., 2005). There were also some studies on HCB pollution of chemical plants in China (Table 1). High levels of HCB were detected in sediment and soil in the Ya-Er lake area in central China, where a factory primarily produced PCP and PCP-Na through HCB (Wu et al., 1997). High levels of HCB were also detected in the sediments from Nanpaiwu River which received the wastewater from a HCB and PCP-Na factory in Tianjin (Hu et al., 2005; Ding et al., 2007). Very high HCB levels in water, soil, sediment and vegetation were observed near a chemical plant using $\mathrm{HCB}$ as a chemical material in Hubei Province (Wang et al., 2007c). Concentrations of HCB in soil were significantly higher in one site near a former organochlorine pesticides (DDT and $\mathrm{HCH}$ ) factory ( $894 \mathrm{ng} / \mathrm{g}$ dry wt.) than those in other locations (0.0531-12.7 ng/g dry wt.) in Anhui Province (Shi et al., 2007a). Moreover, soils were seriously contaminated by HCB in two factories producing PCP and PCP-Na through HCB (SEPA, 2007). These studies indicated that a large amount of HCB emission could be caused by historical wastewater emission and air deposition from these chemical factories. However, there are no detailed data of HCB emissions from the chemical factories. Therefore, it is essential to identify HCB residue levels and potential risk in environmental compartments close to these factories. Furthermore, volatilization of "old" HCB from these contaminated soils need to be studied.

The manufacture of chlorine using carbon anodes is known to produce small amounts of HCB (Bailey, 2001). There is no study about

Table 1

Elevated HCB levels in surrounding environment of chemical plants. ${ }^{a}$

\begin{tabular}{|c|c|c|c|c|}
\hline Location & $\begin{array}{l}\text { Sample } \\
\text { type }\end{array}$ & $\begin{array}{l}\text { Range } \\
\text { (average) }\end{array}$ & $\begin{array}{l}\text { Sampling } \\
\text { year }\end{array}$ & Reference \\
\hline \multirow[t]{2}{*}{ Ya-Er lake } & Sediment & $3.15 \times 10^{7}-5.71 \times 10^{7}$ & 1991-1994 & Wu et al. (1997) \\
\hline & Soil & $3.54 \times 10^{7}-3.77 \times 10^{7}$ & & \\
\hline \multirow{2}{*}{$\begin{array}{l}\text { Nanpaiwu } \\
\text { River }\end{array}$} & Sediment & $799-141000$ & 2002 & Hu et al. (2005) \\
\hline & Sediment & $17.5-1320(240)$ & 2003 & Ding et al. (2007) \\
\hline \multirow{4}{*}{$\begin{array}{l}\text { Hubei } \\
\text { province }\end{array}$} & Water & $2.54-125$ & 2005 & Wang et al. (2007c) \\
\hline & Sediment & $251000-2280000$ & & \\
\hline & Soil & $59.8-1960$ & & \\
\hline & Vegetation & $52.9-687$ & & \\
\hline $\begin{array}{l}\text { Anhui } \\
\text { province }\end{array}$ & Soil & 894 & 2004 & Shi et al. (2007b) \\
\hline
\end{tabular}

${ }^{a}$ HCB in vegetation, sediment and soil is measured with ng/g dry weight, while in water is $\mathrm{ng} / \mathrm{mL}$.
HCB emission from chlorine production using carbon anodes in China. Carbon anodes were eliminated in China according to the regulation issued by the National Development and Reform Commission. It is not a source of HCB in China. HCB was not detected in perchloroethylene with a detection limit of $2 \mathrm{ppb}$ and found at less than $2 \mathrm{ppb}$ in trichloroethylene (IPCS, 1997). Although these chlorinated solvents were produced and used in China, a small amount of HCB could be emitted from their production because of their low emission factors.

\subsubsection{Metals industry and combustion processes}

Hexachloroethane in aluminum oxide can produce small amount of chloro-organics, including HCB (Westberg et al., 1997). Hexachloroethane is still used in molten aluminum process in China, but the amount decreases gradually because of the toxicity of hexachloroethane. Secondary copper recovery was popular in China (the production of recovered copper was 744,026 ton in 2005) (NMII, 2004), which can also lead to HCB emissions. No literature is available about HCB emission from metals industry in China.

In many studies HCB was reported as a product of incomplete combustion where chlorine is present. These combustion processes includes all kinds of waste incineration (hazardous waste, municipal waste, medical waste, and sewage sludge), cement production, iron ore sintering, coal combustion, and biomass burning. Except for sewage sludge incineration (not used in China), other combustion processes may be potential sources of HCB in China. No HCB emission data from combustion processes is available in China. There is no direct regulation on HCB emissions in combustion processes, but some indirect regulations and actions can contribute to reduction of HCB emission. There are complete controlling standards of regular air pollutants and particulate from waste incinerations in China. Moreover, China has planned to phase out the outdated ironstone sinter and electric arc furnace steelmaking techniques. In addition, China is making efforts to reduce emissions of PCDD/Fs from combustion processes by improving combustion condition (SEPA, 2007), which is also expected to reduce HCB emissions.

\section{HCB distribution in the environment}

Compared to the studies on DDT and $\mathrm{HCH}$ residue levels, there are much fewer studies on HCB levels in China. We try to integrate these regional studies to provide a general profile of the spatial and temporal distribution of HCB residue levels in China.

\subsection{Air}

The studies on HCB levels in air in China were conducted in different regions during the period 2000-2007. HCB was detected in all the sampling sites, which implies its long-range transport potential and persistence. Jaward et al. (2005) studied the spatial distribution of HCB concentrations across Asia by passive sampling survey using PUF discs in 2004, which revealed that air HCB levels in China showed much variation, increasing gradually from southwest to northeast (Table 2). It is different from the uniform distribution found in South Korea (14-95 pg/m $\mathrm{m}^{3}$ ), Japan (26-136 pg/m³ ) (Jaward et al., 2005) and Europe $\left(1.4-8.9 \mathrm{pg} / \mathrm{m}^{3}\right.$ ) (Jaward et al., 2004), which indicated that there were some primary emission sources of HCB in China. Although HCB production was completely stopped in 2004, HCB emissions from waste dumpsites and contaminated soils in the former HCB factories in Tianjin and Fuzhou may be responsible for the high air HCB levels in Tianjin, Beijing, and Fuzhou. Air HCB levels in four provinces (Anhui, Hubei, Jiangsu and Hunan province) along the Yangtze River also showed much variation, and there were high HCB levels in limnological regions or the areas around some factories producing pesticides (Shao et al., 2007a). Air HCB concentration $\left(126 \mathrm{pg} / \mathrm{m}^{3}\right.$ ) in Qingdao was similar to the mean $\mathrm{HCB}$ concentration (near $100 \mathrm{pg} / \mathrm{m}^{3}$ ) in China (Lammel et al., 2007). The HCB concentrations in air in the Pearl River Delta were uniform with high concentration/low concentration ratios 
Table 2

HCB levels in air in China.

\begin{tabular}{|c|c|c|c|c|}
\hline Area & $\begin{array}{l}\text { Range/average } \\
\left(\mathrm{pg} / \mathrm{m}^{3}\right)\end{array}$ & Sampling year & $\begin{array}{l}\text { Sampling } \\
\text { method }\end{array}$ & Reference \\
\hline Hong Kong & $46-232(137)$ & $\begin{array}{l}\text { Winter of } \\
2000 / 2001\end{array}$ & Active PUF & $\begin{array}{l}\text { Louie and Sin } \\
\text { (2003) }\end{array}$ \\
\hline Anhui province & $36.6-669$ & \multirow[t]{4}{*}{ 2005.5-2005.10 } & \multirow[t]{4}{*}{ Active PUF } & \multirow{4}{*}{$\begin{array}{l}\text { Shao et al. } \\
\text { (2007a) }\end{array}$} \\
\hline Hubei province & $65-236$ & & & \\
\hline Jiangsu province & $41.1-183$ & & & \\
\hline Hunan province & $21.4-81$ & & & \\
\hline \multirow{2}{*}{$\begin{array}{l}\text { Beijing Tongzhou } \\
\text { district }\end{array}$} & 222 & Spring, 2004 & \multirow[t]{4}{*}{ Active PUF } & \multirow{4}{*}{$\begin{array}{l}\text { Shao et al. } \\
\text { (2007b) }\end{array}$} \\
\hline & 85.3 & Autumn, 2004 & & \\
\hline \multirow{2}{*}{$\begin{array}{l}\text { Beijing Daxing } \\
\text { district }\end{array}$} & 330 & Spring, 2004 & & \\
\hline & 52.7 & Autumn, 2004 & & \\
\hline $\begin{array}{l}\text { Throughout } \\
\text { China }\end{array}$ & $10-460$ & 2004.9-2004.11 & Passive PUF & $\begin{array}{l}\text { Jaward et al. } \\
(2005)\end{array}$ \\
\hline \multirow[t]{2}{*}{ Pearl River Delta } & $\begin{array}{l}27-216 \\
(81)\end{array}$ & $2005.8-10$ & \multirow[t]{2}{*}{ Passive PUF } & \multirow[t]{2}{*}{$\begin{array}{l}\text { Wang et al. } \\
\text { (2007b) }\end{array}$} \\
\hline & $\begin{array}{l}108-567 \\
(257)\end{array}$ & 2005.12-2006.2 & & \\
\hline $\begin{array}{l}\text { The Mt. Everest } \\
\text { region }\end{array}$ & $\begin{array}{l}4.8-12.6 \\
(8.9)\end{array}$ & $2002.5-2002.6$ & Active PUF & Li et al. (2006) \\
\hline Qingdao & 142 & 2003.6 & Active PUF & $\begin{array}{l}\text { Lammel et al. } \\
\text { (2007) }\end{array}$ \\
\hline
\end{tabular}

of 1.7-4.8, which implied the lack of significant primary sources in this area (Wang et al., 2007b). The atmospheric HCB levels in the Mt. Everest region (a remote area far from local sources) were very low ( $\mathrm{Li}$ et al., 2006), which could represent the background levels of HCB in China. HCB levels in air in colder seasons (Winter and Spring) were much higher than those in warmer seasons (Summer and Autumn) in China, which was different from the seasonal variation of other OCP (DDT and Chlordane) levels (Shao et al., 2007b; Wang et al., 2007b). This result also differed from the studies in other countries that HCB levels were higher in warmer season (Ma et al., 2003; Murayama et al., 2003). It proved that temperature did not strongly affect HCB levels in air in China. Some HCB emission sources in colder seasons might be responsible for the higher air HCB levels.

There is only one study on temporal trends of HCB in air in China. HCB levels $\left(46-232 \mathrm{pg} / \mathrm{m}^{3}\right.$ ) in Hong Kong in winter of $2000-2001$ (Louie and Sin, 2003) were similar to the levels $\left(108-189 \mathrm{pg} / \mathrm{m}^{3}\right.$ ) in winter of 2005-2006 (Wang et al., 2007b). Because there were no other studies, it is difficult to estimate the temporal trends of air HCB levels in China.
Compared to other countries, air HCB levels in China were high. Even in the remote area (the Mt. Everest region), air HCB levels were also higher than the levels in Europe $\left(1.4-8.9 \mathrm{pg} / \mathrm{m}^{3}\right.$ ) (Jaward et al., 2004). HCB levels in air were highest in China among the countries (Japan, South Korea, and Singapore) across Asia in 2004. It was similar to air HCB levels $\left(40-340 \mathrm{pg} / \mathrm{m}^{3}\right.$ ) in Great lakes in 1990/1991 (Hoff et al., 1996) and Baikal region (70-170 pg/ $\mathrm{m}^{3}$ ) in 1992 (Iwata et al., 1995). As a whole, HCB air levels in China in the 2000s were similar to those in Europe and USA in the 1990s. This time lag can be mainly attributed to the later production and prohibition of HCB in China.

\subsection{Soil}

The studies on soil HCB residues focused on eastern China (Table 3). The highest levels of HCB in soils were reported at the places where HCB was used or produced in large amounts (Table 1). HCB was not detected in soil samples of Mt. Qomolangma area with the elevation from $4700 \mathrm{~m}$ to $5620 \mathrm{~m}$ (Wang et al., 2007d), much lower than HCB levels (0.13-0.80 ng/g dry wt.) in European Pyrenees mountain soils (Grimalt et al., 2004). There was no study about spatial distribution of soil HCB levels throughout China. According to some regional studies in China, HCB levels in soils increased gradually from south to north China. In Hong Kong, HCB levels were detected from 5 samples out of 46 samples and lower than those in other cities in China (Zhang et al., 2006). In other studies (Table 3), HCB could be detected in most of soil samples. According to three studies in different sampling locations in Beijing, HCB levels in soils of Beijing were distributed in the order: chemical industry zone $(1.85 \pm 1.27 \mathrm{ng} / \mathrm{g}$ dry wt.) > urban $(1.58 \pm 0.68 \mathrm{ng} / \mathrm{g}$ dry wt. $)>$ average Beijing $(0.849 \mathrm{ng} / \mathrm{g}$ dry wt.) (Li et al., 2005; Shi et al., 2007b; Zhou et al., 2007). It indicated that industrial emissions of HCB were the most important sources in this region. In agricultural soils, HCB was also found. HCB levels in arable lands of Pearl River Delta in South China (Wan and Jia, 2005) were much lower than those in Taihu lake region (East China) (Gao et al., 2005; Wang et al., 2007a) and Yangling (Northeast China) (Wang et al., 2006). High HCB levels in agricultural soils in Taihu lake region and Yangling could be attributed to the use of PCP-Na and other pesticides containing $\mathrm{HCB}$ impurity. In comparison, HCB levels in China were lower than those in Katowice $(6.4 \pm 9.6 \mathrm{ng} / \mathrm{g}$ dry wt.), Poland (Falandysz et al., 2001), higher than those in Australia $(<0.2 \mathrm{ng} / \mathrm{g}$ dry wt.) (Cavanagh et al., 1999), while close to global background soil HCB levels (ranging from 0.010 to $5.20 \mathrm{ng} / \mathrm{g}$ dry wt.

Table 3

HCB levels in soil in China.,

\begin{tabular}{|c|c|c|c|c|}
\hline Area & Land use & $\begin{array}{l}\text { Average/range } \\
\text { (ng/g dry weight) }\end{array}$ & Sampling year & Reference \\
\hline Hong Kong & $\begin{array}{l}\text { Woodland, grassland, arable land, } \\
\text { wetland and reclamation land }\end{array}$ & $0.007-0.31$ & 2000.12 & Zhang et al. (2006) \\
\hline Pearl River Delta & Arable land & $\begin{array}{l}\text { ND }-2.12 \\
(0.306)\end{array}$ & 2003.11 & Wan and Jia (2005) \\
\hline \multirow[t]{3}{*}{ Taihu lake region } & Tree land & $(5.13)$ & 2004 & Wang et al. (2007a) \\
\hline & Paddy land & $(3.76)$ & & \\
\hline & Fallow land & $(1.86)$ & & \\
\hline Taihu lake region & Agricultural soils & $0.9-6.2(2.45)$ & & Gao et al. (2005) \\
\hline Lake Tai, Hangzhou Bay and Shanghai city region & Surface soils & $0.08-3.2$ & $2000-2001$ & Nakata et al. (2005a) \\
\hline Anhui province & - & $0.0531-12.7(0.502)$ & $2004.5-2005.6$ & Shi et al. (2007a) \\
\hline Yangling, Shaanxi province & Agricultural soils with wheat-corn rotation & $(2.50)$ & 2000.6 & Wang et al. (2006) \\
\hline Beijing urban city & Urban soils & $0.46-3.17(1.58)$ & 2003 & Li et al. (2005) \\
\hline Chemical industry zone in Beijing & Industrial soils & $\begin{array}{l}\text { ND }-4.12 \\
(1.85)\end{array}$ & 2003.11 & Zhou et al. (2007) \\
\hline Beijing & - & $\begin{array}{l}\text { ND }-6.12 \\
(0.849)\end{array}$ & $2004.5-2004.7$ & Shi et al. (2007a) \\
\hline Qomolangma area & - & ND & 2005.4 & Wang et al. (2007d) \\
\hline
\end{tabular}

a ND: below the detection limit.

b All data base on dry weight. 
Table 4

HCB concentrations in water (ng/L) in China.

\begin{tabular}{|c|c|c|c|}
\hline Location & $\begin{array}{l}\text { Average/range } \\
(\mathrm{ng} / \mathrm{L})\end{array}$ & $\begin{array}{l}\text { Sampling } \\
\text { year }\end{array}$ & Reference \\
\hline Tonghui River, Beijing & $2-660(145)$ & 2003.11 & $\begin{array}{l}\text { Zhou et al. } \\
(2005)\end{array}$ \\
\hline $\begin{array}{l}\text { Guanting reservoir, } \\
\text { Beijing }\end{array}$ & $1.43-27.3(12.4)$ & 2003.11-2004.7,8 & $\begin{array}{l}\text { Xue et al. } \\
(2005)\end{array}$ \\
\hline $\begin{array}{c}\text { Shallow surface ground } \\
\text { water in Taihu basin }\end{array}$ & $0.7-19(3)$ & - & $\begin{array}{l}\text { Li et al. } \\
\text { (2007a) }\end{array}$ \\
\hline Pearl River Estuary & $<1.0-13.6(2.6)$ & 2005.4-2005.11 & $\begin{array}{l}\text { Wei et al. } \\
\text { (2007a) }\end{array}$ \\
\hline $\begin{array}{l}\text { The Nanjing section } \\
\text { of Yangtze river }\end{array}$ & $0.52-0.62$ & 1998.5 & $\begin{array}{l}\text { Jiang et al. } \\
(2000)\end{array}$ \\
\hline Yellow River Estuary & 1260 & 2004.8 & $\begin{array}{l}\text { Jiang et al. } \\
(2006)\end{array}$ \\
\hline Huaihe River & $4700-12200$ & 1998.4-5 & $\begin{array}{l}\text { Wang et al. } \\
(2002)\end{array}$ \\
\hline
\end{tabular}

with a mean of $0.680 \mathrm{ng} / \mathrm{g}$ dry wt.) (Meijer et al., 2003b). There is no available information on temporal distribution of soil HCB levels in China.

\subsection{Water and sediment}

There have been a number of reports about HCB concentrations in water and sediment in China. Most studies focused on rivers, while a few on lake, reservoir, and sea. High HCB levels in water and sediment are supposed to come from point sources producing and using $\mathrm{HCB}$ (Table 1). In the major water systems in China, significant amounts of HCB can be detected (Table 4). HCB levels in the rivers (Huaihe River, Yellow River, Tonghui River) in north China (Wang et al., 2006; Wang et al., 2002; Zhou et al., 2005) were several magnitudes higher than the levels in the rivers (Pearl River and Yangtze River) in South China (Jiang et al., 2000; Wei et al., 2007a). HCB concentrations in water from Beijing Guanting reservoir were generally lower than those in rivers (Xue et al., 2005). HCB concentrations were also detected out in surface ground water in Taihu basin (Li et al., 2007a)(Table 5).

As a river receiving wastewater from many industries, the sediments in the Tonghui River had the highest HCB residues in China (Zhou et al., 2005). In major rivers in China, HCB concentrations in the sediments from the Haihe River were higher than those in other rivers, which indicated the effects of industrial activities (Ding et al., 2006; Jiang et al., 2000; Sun et al., 2007; Yang et al., 2004). HCB concentrations in sediments in the Beijing Guanting reservoir were generally lower than those in rivers (Xue et al., 2005). HCB concentrations in Taihu Lake were higher than those in most of rivers because of industrial discharge to the Lake (Yuan et al., 2003). HCB concentrations in the coastal sediments in the Pearl River Delta were much higher than those in the Pearl River estuary (Fung et al., 2005; Wei et al., 2007a).
Temporal trends of HCB levels were studied in dated sediment cores in Naisihu Lake in Shandong province and coastal areas in Hong Kong (Li et al., 2007b; Wei et al., 2008). HCB concentrations in Naisihu Lake increased significantly from $0.80 \mathrm{ng} / \mathrm{g}$ dry wt. to $2.27 \mathrm{ng} / \mathrm{g}$ dry wt. over the period 1960-2000. In Hong Kong, HCB in coastal sediments was first detected in the 1940s, and two peak-time periods were observed in the 1960s and 1990s, which didn't show a decreasing trend either. The results were different from decreasing trends of HCB concentrations in the sediments in other countries, because HCB was produced from 1958 to 2003 in China while its production and use was banned in most of the other countries before the 1980s.

\subsection{Vegetation}

Vegetation can serve as a biomonitor to trace the levels of atmospheric contamination of HCB. HCB concentrations in pine needles were determined in six regions of China in 2001 (Xu et al., 2004b). There was significant positive correlation between the GDP per capita and the concentration of $\mathrm{HCB}$ in pine needles. The high levels of $\mathrm{HCB}$ were found at relatively high-income areas in East China. HCB levels in pine needles at the chemical industrial area $(5.3 \mathrm{ng} / \mathrm{g}$ dry wt.) were higher than those at the residential area near chemical industries ( $2.9 \mathrm{ng} / \mathrm{g}$ dry wt.) and residential area ( $1.1 \mathrm{ng} / \mathrm{g}$ dry wt.) in Beijing in 2002 (Xu et al., 2004a), which indicated that HCB in Beijing was mainly from chemical industries. Another study in 2003 showed that HCB could be found in $100 \%$ of the leaf samples from the plants in Beijing's southeast chemical industrial zone (Zhou et al., 2007). Around the sewage ditch from a chemical plant using HCB as industrial material in Hubei Province, the roots of vegetation were seriously contaminated by HCB (52.9-687 ng/g dry wt.). Lower concentrations (ND $-18.4 \mathrm{ng} / \mathrm{g}$ dry wt.) in vegetations further from the chemical plant showed the indicative of vegetation to HCB emissions (Wang et al., 2007c). In remote area of Qomolangma in China, HCB levels (0.0156-1.25 ng/g dry wt.) in grasses were detected. The significant correlation between HCB levels and the altitude suggests that cold condensation was occurring in elevated areas (Wang et al., 2007d). In remote area of southeast Tibet, HCB could also be detected in conifer needles (Yang et al., 2008). HCB levels in the needles in China are similar to those (1.4-30 ng/g dry wt.) in Europe (Calamari et al., 1994; Holoubek et al., 2007), but are generally higher than those in Africa and Canada (Davidson et al., 2004; Tremolada et al., 1993)(Table 6).

\subsection{Biota}

\subsubsection{Bird}

HCB concentrations in eggs of Egiretta garzetta in Poyang Lake (3.3 ng/g dry wt.) and Taihu lake (6.3 ng/g dry wt.) were investigated, and the contamination levels did not affect the development and breeding success of E. garzetta (Ruan et al., 2003). HCB concentrations in Acrocephalus aedon around Taihu Lake in 2000 were $32 \pm 23 \mathrm{ng} / \mathrm{g}$

Table 5

HCB concentrations in sediments (ng/g) in China. ${ }^{a}$

\begin{tabular}{|c|c|c|c|}
\hline Location & $\begin{array}{l}\text { Average/range } \\
\text { (ng/g) }\end{array}$ & Sampling year & Reference \\
\hline Guanting reservoir, Beijing & $0.0552-0.494(0.146)$ & 2003.11-2004.7,8 & Xue et al. (2005) \\
\hline Tonghui River, Beijing & $(135)$ & 2003.11 & Zhou et al. (2005) \\
\hline Haihe River, Tianjin & $6.8-16.7(11.9)$ & - & Ding et al. (2006) \\
\hline Middle and lower reaches of the Yellow River & $0.03-4.58$ & 2005.11 & Sun et al. (2007) \\
\hline Nanjing section of Yangtze river & $1.2-6.6(4.1)$ & 1998.5 & Jiang et al. (2000) \\
\hline Taihu Lake & $0.06-9.69(2.16)$ & Spring and Summer, 2000 & Yuan et al. (2003) \\
\hline Huangpu River & 3.2 & 2001.9 & Nakata et al. (2005a) \\
\hline Wuhan section of Yangtze river & $0.94-4.39(1.86)$ & 2001.10 & Yang et al. (2004) \\
\hline Pearl River Estuary & $0.26-1.82(0.69)$ & 2005.4 & Wei et al. (2007a) \\
\hline Coastal sediments in the Pearl River Delta & $1.1-55$ & 2003.03 & Fung et al. (2005) \\
\hline
\end{tabular}

a All data base on dry weight. 
Table 6

HCB concentrations in vegetation in China. ${ }^{\mathrm{a}, \mathrm{b}}$

\begin{tabular}{|c|c|c|c|c|}
\hline Location & $\begin{array}{l}\text { Range/average } \\
\text { (ng/g) }\end{array}$ & Vegetation types & $\begin{array}{l}\text { Sampling } \\
\text { time }\end{array}$ & Reference \\
\hline 18 areas in China & $\mathrm{ND}-11.7(4.2)$ & Needles & 2001 & $\begin{array}{l}\text { Xu et al. } \\
\text { (2004b) }\end{array}$ \\
\hline Beijing City & $1.1-5.3(2.3)$ & Needles & $2002.3-4$ & $\begin{array}{l}\text { Xu et al. } \\
(2004 a)\end{array}$ \\
\hline $\begin{array}{l}\text { Chemical industrial } \\
\text { zone in Beijing }\end{array}$ & $\begin{array}{l}0.132-2.14 \\
(1.44)\end{array}$ & $\begin{array}{l}\text { Leaves of some } \\
\text { redwood and grass }\end{array}$ & 2003.11 & $\begin{array}{l}\text { Zhou et al. } \\
\text { (2007) }\end{array}$ \\
\hline $\begin{array}{c}\text { Qomolangma area } \\
(4700-5600 \mathrm{~m})\end{array}$ & $0.0156-1.25$ & $\begin{array}{l}\text { Grasses Jidou } \\
\text { and Rouzi }\end{array}$ & 2005.4 & $\begin{array}{l}\text { Wang et al. } \\
\text { (2007d) }\end{array}$ \\
\hline $\begin{array}{l}\text { Southeast Tibetan } \\
\text { Plateau }\end{array}$ & $0.69-4.3$ & Needles & 2006.5 & $\begin{array}{l}\text { Yang et al. } \\
(2008)\end{array}$ \\
\hline
\end{tabular}

a ND: below the detection limit.

b All data based on dry weight.

lipid wt. (Nakata et al., 2005a). No other studies on HCB levels in birds were conducted in China.

\subsubsection{Fish and shellfish}

HCB levels in fish and shellfish in China were studied widely. Concentrations of $\mathrm{HCB}$ in fishes from Taihu Lake were relatively consistent, ranging from $20 \mathrm{ng} / \mathrm{g}$ lipid wt. in spotted steed to $37 \mathrm{ng} / \mathrm{g}$ lipid wt. in topmouth clulter. HCB levels in shrimp and farm-raised carp around Taihu lake were relatively low (11-14 ng/g lipid wt.) (Nakata et al., 2005a). Concentrations of OCPs in different tissues of Chinese Sturgeon were investigated (Wan et al., 2007). HCB was detected in all the samples, and HCB concentrations (224-2600 ng/g lipid wt.) in Chinese Sturgeon muscles were comparable to those in sturgeons collected from the Caspian Sea (Kajiwara et al., 2003).

The studies on HCB in halobios focused on mussels. In the study by Monirith et al., HCB concentrations were generally uniform in China excluding extremely high HCB levels ( $540 \mathrm{ng} / \mathrm{g}$ lipid wt.) in samples collected from Jiao Zhou Bay, Shandong province. If the sites with extreme high concentration are excluded, HCB levels of mussels in China were similar to those in South Korea and Japan, but higher than those in Vietnam and Philippines (Monirith et al., 2003). In the study by Ramu et al., the distribution of HCB in mussels was comparable with the previous study, but the maximum level of HCB in mussel was $12 \mathrm{ng} / \mathrm{g}$ lipid wt. HCB concentrations in China were lower than those in South Korea and similar to those in Japan (Ramu et al., 2007). In two studies, HCB levels in mussels increased from south to north in China. The chemical factories producing HCB in Tianjin and Fuzhou may contribute to the unusually high HCB concentrations in mussels from Bohai Sea and Fuzhou. HCB concentrations in bivalves collected from Pearl River Estuary were comparatively low, except for HCB levels in bivalves from one site (26.8 and $14.9 \mathrm{ng} / \mathrm{g}$ dry wt.) (Wei et al., 2006). Almost all of the shrimp samples had extremely low levels of HCB $(<0.5 \mathrm{ng} / \mathrm{g}$ dry wt.), except for the samples from the site (1.14 ng/g dry wt.). In marine fishes in Hangzhou Bay, HCB levels ranged from the detection limit in halfsmooth tonguefish to $61 \mathrm{ng} / \mathrm{g}$ lipid wt. in trident goby. No significant difference in HCB concentrations was observed between fishes from Taihu Lake and Hangzhou Bay (Nakata et al., 2005a). HCB levels in fish in China were higher than those (1.67-4.53 ng/g lipid wt.) in eastern and southern Asia (India, Thailand, Vietnam, Indonesia, Papua New Guinea, and the Solomon Islands), but were lower than those in Australia and Europe (124 ng/g lipid wt.) (Kannan et al., 1995; Falandysz et al., 1994). In the study using skipjack tuna as a bioindicator of global PCBs and OCPs monitoring, HCB levels in the liver of skipjack tuna in the East China Sea $(<0.16-7.0 \mathrm{ng} / \mathrm{g}$ lipid wt.) and South China Sea (2.2 ng/g lipid wt.) were medium in global environment (Ueno et al., 2003). HCB was detected in all the blubber of finless porpoises collected from South China Sea in 1990 (140-230 ng/g lipid wt.) and 2000/2001 (87$250 \mathrm{ng} / \mathrm{g}$ lipid wt.), concentrations of HCB in finless porpoises did not change significantly in the last decade (Ramu et al., 2006). There are no other studies about temporal trend of HCB in fish and shellfish (Table 7).

\subsection{Sewage sludge}

HCB levels were detected in sewage sludge from wastewater treatment plants in two studies. According to the study (Cai et al., 2007), samples were collected from 1998 to 1999 from 9 cities in China. HCB was detected in all samples with the levels from 9 to $3170 \mathrm{ng} / \mathrm{g}$ dry wt. (mean: $584 \mathrm{ng} / \mathrm{g}$ dry wt.). In another study by (Wang et al., 2007e), 31 sewage sludge samples in total were collected from 26 cities in 2005 in China. The concentrations of HCB ranged from $7.5 \mathrm{ng} / \mathrm{g}$ to $319 \mathrm{ng} / \mathrm{g}$ dry wt., with an average of $145 \mathrm{ng} / \mathrm{g}$ dry wt. HCB levels in sewage sludge were significantly higher than those in the river sediments (Table 5) in China, which indicated that wastewater was also a pollution source of HCB.

\section{Human exposure}

\subsection{HCB residues in food and human exposure}

There were some studies on HCB residue levels in various food groups in China. HCB levels in butter collected from 23 countries were determined, with particularly high levels recorded in the sample (6.15 ng/g lipid wt.) from China (Kalantzi et al., 2001). The dietary intakes of HCB by the general population were evaluated in some studies after 2000 (Table 8). These studies focused on eastern China. In all the studies, the estimated daily intakes of HCB were much lower than Canadian tolerable daily intake ( $270 \mathrm{ng} / \mathrm{kg}$ body weight/day), indicating that the intakes would not pose a health risk in China at the present (Nakata et al., 2002; Wei et al., 2006; Yang et al., 2006;

Table 7

$\mathrm{HCB}$ concentrations in fish and shellfish in China.

\begin{tabular}{|c|c|c|c|c|}
\hline Location & $\begin{array}{l}\text { Range/average } \\
\text { (ng/g lipid wt.) }\end{array}$ & Sample types & Sampling time & Reference \\
\hline Taihu Lake & $11-37$ & $\begin{array}{l}\text { Carp, catfish, spotted steed } \\
\text { topmouth culter and shrimp }\end{array}$ & 2000.8 & Nakata et al. (2005a) \\
\hline Han Zhou Bay & $<0.01-61(16)$ & 11 species of fishes and shrimps & 2001.9 & \\
\hline Along the Coast of China & $<1-12$ & Mussels (Mytilus edulis and Perna viridis) & 2003-2005 & Ramu et al. (2007) \\
\hline Hong Kong & $<1$ & & & \\
\hline Along the Coast of China & $<0.5-540(56)$ & Mytilus edulis and Perna viridis & 1999-2001 & Monirith et al. (2003) \\
\hline Hong Kong & $<0.50-<1.5(<1.0)$ & & 1998-1999 & \\
\hline East China Sea & $<0.16-7.0(2.1)$ & Skipjack tuna liver & 1997 & Ueno et al. (2003) \\
\hline South China sea & 2.2 & & 2001 & \\
\hline Yangtze River & $224-2600$ & Chinese sturgeon muscle & 2003-2005 & Wan et al. (2007) \\
\hline Dong shan & $140-230$ & Blubber of finless porpoises & 1990 & Ramu et al. (2006) \\
\hline Hong Kong & $87-250$ & & 2000-2001 & \\
\hline
\end{tabular}


Table 8

Food residue levels and estimated dietary intake (EDI) of HCB in China. ${ }^{a, b, c}$

\begin{tabular}{|c|c|c|c|c|c|}
\hline Location & Food group & $\begin{array}{l}\text { Range/average } \\
\text { (ng/g) }\end{array}$ & $\begin{array}{l}\text { HCB EDI } \\
\text { (ng/kg bw/day) }\end{array}$ & Sampling time & Reference \\
\hline Pearl River Delta & $\begin{array}{l}\text { Mussel and oyster } \\
\text { Shrimp }\end{array}$ & $\begin{array}{l}0.30-26.8^{\mathrm{a}} \\
<0.05-1.14^{\mathrm{a}}\end{array}$ & $1.4 \times 10^{-3}-8.0$ & 2003.3 & Wei et al. (2006) \\
\hline $\begin{array}{l}\text { Local supermarkets of Dalian, } \\
\text { Tianjin Shanghai }\end{array}$ & Fish and shellfish & $\begin{array}{l}0.01-2.28^{\mathrm{b}} \\
(0.38)\end{array}$ & 0.19 & 2002.4 & Yang et al. (2006) \\
\hline Pingqiao, Zhejiang province & $\begin{array}{l}\text { Rice } \\
\text { Hen egg } \\
\text { Crucian carp }\end{array}$ & $\begin{array}{l}44.7-83.5^{\mathrm{a}} \\
\text { (median: } 52.1 \text { ) } \\
0.03-536^{\mathrm{a}} \\
(\text { median : } 135) \\
0.03-11.8^{\mathrm{a}} \\
(\text { median }: 1.70)\end{array}$ & 0.3 & $2003.10-2005.6$ & Zhao et al. (2007) \\
\hline Luqiao, Zhejiang province & $\begin{array}{l}\text { Rice } \\
\text { Hen egg } \\
\text { Crucian carp }\end{array}$ & $\begin{array}{l}29.8-78.1^{\mathrm{a}} \\
\text { (median: } 70.6 \text { ) } \\
0.15-396^{\mathrm{a}} \\
\text { (median: } 107 \text { ) } \\
0.03-2.71^{\mathrm{a}} \\
\text { (median: } 0.39 \text { ) }\end{array}$ & 0.3 & & Zhao et al. (2007) \\
\hline Shanghai and its vicinity (Yixing) & $\begin{array}{l}\text { Seafoods } \\
\text { Meat } \\
\text { Cereals } \\
\text { Fruits } \\
\text { Vegetables } \\
\text { Tea leaves } \\
\text { Others } \\
\text { (mud snail, crawfish milk } \\
\text { sunflower seed egg pulse oil) }\end{array}$ & $\begin{array}{l}<0.01-0.24^{\mathrm{b}} \\
<0.01-0.37^{\mathrm{b}} \\
<0.01^{\mathrm{b}} \\
<0.01-0.04^{\mathrm{b}} \\
<0.01-0.75^{\mathrm{b}} \\
0.79-3.1^{\mathrm{b}} \\
<0.01-1.0^{\mathrm{b}}\end{array}$ & $46 / 60=0.77$ & $2001.8-2002.4$ & Nakata et al. (2002) \\
\hline Local market in Zhoushan City & Fishes & $0.07-2.0^{\mathrm{b}}$ & Not available & 2003.10 & Jiang et al. (2005) \\
\hline
\end{tabular}

Zhao et al., 2007). They were also lower than the daily intakes of HCB in India (1989), Thailand (1988), Vietnam (1990), and Japan (1992) (Kannan et al., 1997). However, the cancer risks associated with fish consumption based on 95th centile concentrations of HCB were greater than unity, suggesting that daily exposure to HCB due to fish consumption had a lifetime cancer risk of greater than one in one million in Zhoushan city (Jiang et al., 2005). It proves that HCB levels in foods need to be taken into consideration of potential health risk in China, although the risks are low at the present.

\subsection{HCB residues in human milk and tissue}

The studies on HCB concentrations in human tissues in China mainly focused on human adipose tissue and human milk (Table 9). HCB levels in human adipose tissues in Guizhou province (Nakata et al., 2005b) and Shanghai city (Nakata et al., 2002) were comparable to those in Japan (Minh et al., 2000) and Mexico (Waliszewski et al., 1999) and slightly higher than those in the United States (ArchibequeEngle et al., 1997) and Korea (Kang et al., 1997). Most of human milk samples were collected from eastern China during the period 1987-2005. HCB could be detected in all the studies, but HCB levels in various areas ranged widely (Kunisue et al., 2004; Zhao et al., 2007). Human milk from some cities such as Changsha, Shijiazhuang had high HCB concentrations (Cao et al., 2000; Sun et al., 2005). HCB levels in China were relatively higher compared to those in the US and other Asian countries (Tanabe and Kunisue, 2007; Johnson-Restrepo et al., 2007). It is concerned that estimated daily intake ( $0.15 \mathrm{ng} / \mathrm{g}$ body wt./ day) of HCB by infants from breast milk was close to tolerable daily intake $(0.27 \mathrm{ng} / \mathrm{g}$ body wt./day). Temporal trends of HCB in human milk have been reported in China. HCB levels in milk decreased obviously in Beijing from 1988 to 2002 and in Changchun city from 1987 to 1998 (Li et al., 2000; Yu et al., 2005a), while increased by 60\% in Changsha from 1988 to 1998 (Cao et al., 2000). The differences in temporal changes of HCB may be related to HCB emissions of point sources in China.

\section{Conclusion}

In China, the characteristics of HCB production and usage were different from other countries. HCB was produced from 1958 to 2003 in China, although it was banned in most of countries before the 1980s. Large amount of HCB was produced in China. Most of HCB was used as an intermediate for producing PCP and PCP-Na. There was no direct use

Table 9

HCB residue levels in human milk and tissue in China.

\begin{tabular}{|c|c|c|c|c|}
\hline Location & $\begin{array}{l}\text { Type of } \\
\text { human tissue }\end{array}$ & $\begin{array}{l}\text { Range/median } \\
\text { (mg/kg lipid wt.) }\end{array}$ & $\begin{array}{l}\text { Sampling } \\
\text { year }\end{array}$ & Reference \\
\hline Beijing & Human milk & Median: 0.02-0.07 & 1988-2002 & $\begin{array}{l}\text { Yu et al. } \\
\text { (2005b) }\end{array}$ \\
\hline Changsha & Human milk & $\begin{array}{l}0.01-0.24(0.06) \\
0.06-0.81(0.19)\end{array}$ & $\begin{array}{l}1988 \\
1998\end{array}$ & $\begin{array}{l}\text { Cao et al. } \\
(2000)\end{array}$ \\
\hline Changchun & Human milk & $\begin{array}{l}0.22 \\
0.0595(0.06)\end{array}$ & $\begin{array}{l}1987 \\
1998\end{array}$ & $\begin{array}{l}\text { Li et al. } \\
(2000)\end{array}$ \\
\hline Dalian & Human milk & $\begin{array}{l}0.03-0.22(\text { mean } \\
0.081 \pm 0.046)\end{array}$ & 2002.11-12 & $\begin{array}{l}\text { Kunisue } \\
\text { et al. }\end{array}$ \\
\hline Shenyang & & $\begin{array}{l}0.025-0.12 \\
(\text { mean } 0.056 \pm 0.03)\end{array}$ & & (2004) \\
\hline $\begin{array}{l}\text { Shijiazhuang } \\
\text { city }\end{array}$ & Human milk & $\begin{array}{l}0.102 \\
\text { (G mean: 0.0978) }\end{array}$ & 2002.11 & $\begin{array}{l}\text { Sun et al. } \\
(2005)\end{array}$ \\
\hline $\begin{array}{l}\text { Tangshan } \\
\text { countryside }\end{array}$ & & $\begin{array}{l}0.0876 \\
\text { ( } G \text { mean: } 0.0846)\end{array}$ & 2003.08 & \\
\hline $\begin{array}{l}\text { Luqiao, } \\
\text { Zhejiang } \\
\text { province }\end{array}$ & Human milk & $\begin{array}{l}0.01-262 \mathrm{ng} / \mathrm{g} \\
(38.5)\end{array}$ & $\begin{array}{l}2003.10- \\
2005.06\end{array}$ & $\begin{array}{l}\text { Zhao et al. } \\
\text { (2007) }\end{array}$ \\
\hline $\begin{array}{l}\text { Pingqiao, } \\
\text { Zhejiang } \\
\text { Province }\end{array}$ & & $\begin{array}{l}23.6-65.8 \mathrm{ng} / \mathrm{g} \\
(48.2)\end{array}$ & & \\
\hline $\begin{array}{l}\text { Guizhou } \\
\text { Province, } \\
\text { southern } \\
\text { China }\end{array}$ & $\begin{array}{l}\text { Human adipose } \\
\text { tissues }\end{array}$ & $\begin{array}{l}7.6-100 \mathrm{ng} / \mathrm{g} \\
(\text { mean: } 40 \pm 19)\end{array}$ & 2002 & $\begin{array}{l}\text { Nakata } \\
\text { et al. } \\
\text { (2005b) }\end{array}$ \\
\hline Shanghai & $\begin{array}{l}\text { Human adipose } \\
\text { tissues }\end{array}$ & $\begin{array}{l}28-127 \mathrm{ng} / \mathrm{g} \\
\text { (mean: } 64 \pm 37 \text { ) }\end{array}$ & 2001 & $\begin{array}{l}\text { Nakata } \\
\text { et al. } \\
(2002)\end{array}$ \\
\hline
\end{tabular}


of HCB in agriculture in China. Moreover, most PCP-Na produced through HCB was used as a molluscicide in limnological regions of south China. Some chemical plants producing and using HCB caused serious HCB pollution. There are some potential unintended HCB emission sources but little information of detailed emission from these sources in China. Pesticides application may be an important HCB emission source because of their high emission factors and vast use. Other sources cannot be omitted due to the uncertain factors associated with such emissions. Because of the prohibition of HCB, PCP-Na and PCP, technical innovation and implementation of stricter environmental regulations, HCB emission is expected to reduce in China.

$\mathrm{HCB}$ is widely distributed in various environmental compartments in China. HCB can be detected even in remote areas. HCB levels increased from South China to North China in most of environmental compartments (air, soil, and mussel). Except for high HCB levels in air and human milk, HCB levels in other environmental compartments in China are similar to those in Europe and eastern Asia from regional perspective. Moreover, HCB levels in air and shellfish tend to much variation, which are different from the uniform distribution in Europe and eastern Asia, indicating that there are some primary emission sources of HCB in China. High HCB concentrations in air, soil and vegetation are found near industrial areas, especially the plants producing and using $\mathrm{HCB}$.

In general, HCB in food and human milk is not expected to pose a health risk in China at the present, although HCB levels in human milk and some foods were higher than those in most of other countries. However, the increasing trend of HCB levels in human milk in some areas needs to be taken into consideration. In addition, long-term exposure to HCB should not be overlooked.

In the limited studies, the temporal trends of HCB levels in the environment in different areas were various. HCB levels in some areas were decreased obviously, but increased strikingly in other areas. In addition, air HCB levels in the colder season were much higher than the warmer season. Some sources of HCB emissions in colder season may be responsible for the elevated levels.

Further studies need to be performed on HCB emission inventories in China, HCB levels in central China and western China, and temporal trends of HCB levels in China. Direct regulations and policies for control over HCB emissions should be developed based on the results of the studies on HCB.

\section{Acknowledgement}

This study was supported by the National Basic Research Program of China ('973' Research Program) with Grant No. 2007CB407307 and the Knowledge Innovation Program of the Chinese Academy of Sciences, with Grant No. KZCX2-YW-420-5.

\section{References}

ArchibequeEngle SL, Tessari JD, Winn DT, Keefe TJ, Nett TM, Zheng TZ. Comparison of organochlorine pesticide and polychlorinated biphenyl residues in human breast adipose tissue and serum. J Toxicol Env Health 1997;52:285-93.

Bailey RE. Global hexachlorobenzene emissions. Chemosphere 2001;43:167-82.

Barber JL, Sweetman AJ, van Wijk D, Jones KC. Hexachlorobenzene in the global environment: Emissions, levels, distribution, trends and processes. Sci Total Environ 2005;349:1-44.

Benazon N. Hexachlorobenzene emissions/releases inventory for Ontario 1988, 1998 and 2000. Draft Report for Environment Canada 1999.

Braune BA. Temporal trends of organochlorines and mercury in seabird eggs from the Canadian Arctic, 1975-2003. Environ Pollut 2007:148:599-613.

Bustnes JO, Yoccoz NG, Bangjord G, Polder A, Skaare JU. Temporal trends (1986-2004) of organochlorines and brominated flame retardants in tawny owl eggs from northern Europe. Environ Sci Technol 2007;41:8491-7.

Cai QY, Mo CH, Wu QT, Zeng QY, Katsoyiannis A. Occurrence of organic contaminants in sewage sludges from eleven wastewater treatment plants, China. Chemosphere 2007;68:1751-62.

Calamari D, Tremolada P, Diguardo A, Vighi M. Chlorinated hydrocarbons in pine needles in Europe - fingerprint for the past and recent use. Environ Sci Technol 1994;28:429-34.

Cao HJ, Cao ZH, Hu XH, Zhou XD, Yang Y, Wang WH, et al. Dynamic study on the organic chloride level in human breast milk in Changsha District (in Chinese). Pract prev med 2000;7:172-4.
Cavanagh JE, Burns KA, Brunskill GJ, Coventry RJ. Organochlorine pesticide residues in soils and sediments of the Herbert and Burdekin river regions, North Queensland implications for contamination of the Great Barrier Reef. Mar Pollut Bull 1999;39:367-75.

Corsolini S, Kannan K, Imagawa T, Focardi S, Giesy JP. Polychlorinated naphthalenes (PCNs) and other dioxin-like compounds in Arctic and Antarctic marine food webs. Environ Sci Technol 2002;36:3490-6.

Courtney KD. Hexachlorobenzene (HCB): A review. Environ Res 1979;2:225-66.

Davidson DA, Wilkinson AC, Kimpe LE, Blais JM. Persistent organic pollutants in air and vegetation from the Canadian Rocky Mountains. Environ Toxicol Chem 2004;23: $540-9$.

Ding H, Li XG, Xu SM, Sun YC, Shao XL. Desorption of HCB in sediments from Dagu drainage River. J Tianjin Univ 2007;40:1309-12.

Ding H, Wang SQ, Sun JS, Li XG, Sun YC, Shao XL, et al. HCB residue and desorption kinetics of HCB in sediments from Haihe Rivermain branch (in Chinese). Environ Sci 2006;27:533-7.

Falandysz J, Brudnowska B, Kawano M, Wakimoto T. Polychlorinated biphenyls and organochlorine pesticides in soils from the southern part of Poland. Arch Environ Con Tox 2001;40:173-8.

Falandysz J, Kannan K, Tanabe S, Tatsukawa R. Organochlorine pesticides and polychlorinated biphenyls in cod-liver oils: North Atlantic, Norwegian Sea, North Sea and Baltic Sea. Ambio 1994;23:288-93.

Fung CN, Zheng GJ, Connell DW, Zhang X, Wong HL, Giesy JP, et al. Risks posed by trace organic contaminants in coastal sediments in the Pearl River Delta, China. Mar Pollut Bull 2005;50:1036-49.

Gao HJ, Jiang X, Wang F, Bian YR, Wang DZ, Dend JC, et al. Residual levels and new inputs of chlorinated POPs in agricultural soils from Taihu Lake region. Pedosphere 2005;15:301-9.

Grimalt JO, van Drooge BL, Ribes A, Vilanova RM, Fernandez P, Appleby P. Persistent organochlorine compounds in soils and sediments of European high altitude mountain lakes. Chemosphere 2004;54:1549-61.

Hoff RM, Strachan WMJ, Sweet CW, Chan CH, Shackleton M, Bidleman TF, et al. Atmospheric deposition of toxic chemicals to the Great Lakes: a review of data through 1994. Atmos Environ 1996;30:3505-27.

Holoubek I, Klanova J, Jarkovsky J, Kubik V, Helesic J. Trends in background levels of persistent organic pollutants at Kosetice observatory, Czech Republic. Part II. Aquatic and terrestrial environments 1996-2005. J Environ Monit 2007;9:564-71.

Hu JY, Wan Y, Shao B, Jin XH, An W, Jin F, et al. Occurrence of trace organic contaminants in Bohai Bay and its adjacent Nanpaiwu River, North China. Mar Chem 2005;95: $1-13$.

IPCS, International Programme on Chemical Safety. Environmental Health Criteria 195. Hexachlorobenzene. Geneva: World Health Organization; 1997.

Iwata H, Tanabe S, Ueda K, Tatsukawa R. Persistent organochlorine residues in air, water, sediments, and soils from the Lake Baikal Region, Russia. Environ Sci Technol 1995;29:792-801.

Jaward FM, Farrar NJ, Harner T, Sweetman AJ, Jones KC. Passive air sampling of PCBs, PBDEs, and organochlorine pesticides across Europe. Environ Sci Technol 2004;38:34-41.

Jaward TM, Zhang G, Nam JJ, Sweetman AJ, Obbard JP, Kobara Y, et al. Passive air sampling of polychlorinated biphenyls, organochlorine compounds, and polybrominated diphenyl ethers across Asia. Environ Sci Technol 2005;39:8638-45.

Jiang QT, Lee TKM, Chen K, Wong HL, Zheng JS, Giesy JP, et al. Human health risk assessment of organochlorines associated with fish consumption in a coastal city in China. Environ Pollut 2005;136:155-65.

Jiang X, Xu SF, Martens D, Wang LS. Polychlorinated organic contaminants in waters, suspended solids and sediments of the Nanjing section, Yangtze River (in Chinese). China Environ Sci 2000;20:193-7.

Jiang FX, Liu ZT, Feng L, Wang WH. Character analysis of organic pollutants in Yellow River estuary area (in Chinese). Research of Environmental Sciences 2006;19:6-10.

Johnson-Restrepo B, Addink R, Wong C, Arcaro K, Kannan K. Polybrominated diphenyl ethers and organochlorine pesticides in human breast milk from Massachusetts, USA. J Environ Monit 2007;9:1205-12.

Kajiwara N, Ueno D, Monirith I, Tanabe S, Pourkazemi M, Aubrey DG. Contamination by organochlorine compounds in sturgeons from Caspian Sea during 2001 and 2002. Mar Pollut Bull 2003;46:741-7.

Kalantzi OI, Alcock RE, Johnston PA, Santillo D, Stringer RL, Thomas GO, et al. The global distribution of PCBs and organochlorine pesticides in butter. Environ Sci Technol 2001;35:1013-8.

Kang YS, Matsuda M, Kawano M, Wakimoto T, Min BY. Organochlorine pesticides, polychlorinated biphenyls, polychlorinated dibenzo-p-dioxins and dibenzofurans in human adipose tissue from western Kyungnam, Korea. Chemosphere 1997;35:2107-17.

Kannan K, Falandysz J, Yamashita N, Tanabe S, Tatasukawa R. Temporal trends of organochlorine concentrations in cod-liver oil from the Southern Baltic Proper, 1971-1989. Mar Pollut Bull 1992;24:358-63.

Kannan K, Tanabe S, Giesy JP, Tatsukawa R. Orgaochlorine pesticides and polychlorinated biphenyls in foodstuffs from Asian and Oceanic countries. Rev Environ Contam T 1997;152:1-55.

Kannan K, Tanabe S, Tatsukwawa R. Geographical distribution and accumulation features of organochlorine residues in fish in Asia and Oceania. Environ Sci Technol 1995;29:2673-83.

Kannan K, Yun SH, Evans TJ. Chlorinated, brominated and perfluorinated contaminants in livers of polar bears from Alaska. Environ Sci Technol 2005;39:9057-63.

Kunisue T, Someya M, Kayama F, Jin Y, Tanabe S. Persistent organochlorines in human breast milk collected from primiparae in Dalian and Shenyang, China. Environ Pollut 2004;131:381-92.

Lammel G, Ghim YS, Grados A, Gao HW, Huhnerfuss H, Lohmann R. Levels of persistent organic pollutants in air in China and over the Yellow Sea. Atmos Environ 2007;41:452-64. 
Li BH, Ren ZY, Chen HH, Cao XJ, Liu F. Residues of organochlorine pesticides in shallow groundwater of agricultural region in Taihu Basin (in Chinese). J Agro-Environ Sci 2007a;26:1714-8.

Li HL, Li GG, Yang F, Gao H. Vertical distribution characteristics of organochlorine pesticides and polychlorinated biphenyls in sediment core from Lake Nansihu (in Chinese). Environ Sci 2007b;28:1590-4.

Li XH, Ma LL, Liu XF, Fu S, Cheng HX, Xu XB. Distribution of organochlorine pesticides in urban soil from Beijing, People's Republic of China. B Environ Contam Tox 2005;74:938-45.

Li YH, Wang G, Zhu YL, Li DY, Liang CJ, Tian FH. Accumulative levels of organochlorine pesticides among women during their lactation period in Changchun (in Chinese). J Environ Health 2000;17:18-20.

Li J, Zhu T, Wang F, Qiu XH, Lin WL. Observation of organochlorine pesticides in the air of the Mt. Everest region. Ecotox Environ Safe 2006;63:33-41.

Louie PKK, Sin DWM. A preliminary investigation of persistent organic pollutants in ambient air in Hong Kong. Chemosphere 2003;52:1397-403.

Lu Y. Determination of hexachlorobenzene pesticide residues in picloram by capillary gas chromatography-negative chemical ionization mass spectrometry analysis (in Chinese). Multipurpose Utilization of Mineral Resources; 2007. p. 44-8.

H.M.Ma HM, S.Venkatesh S, L.M.Jantunen LM. Evidence of the impact of ENSO events on temporal trends of hexachlorobenzene air concentrations over the Great Lakes. Sci Total Environ 2003;313:177-84.

Meijer SN, Ockenden WA, Steinnes E, Corrigan BP, Jones KC. Spatial and temporal trends of POPs in Norwegian and UK background air: Implications for global cycling. Environ Sci Technol 2003a;37:454-61.

Meijer SN, Ockenden WA, Sweetman A, Breivik K, Grimalt JO, Jones KC. Global distribution and budget of PCBs and HCB in background surface soils: Implications or sources and environmental processes. Environ Sci Technol 2003b;37:667-72.

Minh TB, Prudente MS, Watanabe M, Tanabe S, Nakata H, Miyazaki N, et al. Recent contamination of persistent chlorinated endocrine disrupters in cetaceans from the North Pacific and Asian coastal waters. Water Sci Technol 2000;42:231-40.

Monirith I, Ueno D, Takahashi S, Nakata H, Sudaryanto A, Subramanian A, et al. AsiaPacific mussel watch: monitoring contamination of persistent organochlorine compounds in coastal waters of Asian countries. Mar Pollut Bull 2003;46:281-300.

Murayama H, Takase Y, Mitobe H, Mukai H, Ohzeki T, Shimizu K, et al. Seasonal change of persistent organic pollutant concentrations in air at Niigata area, Japan. Chemosphere 2003;52:683-94.

Nakata H, Hirakawa Y, Kawazoe M, Nakabo T, Arizono K, Abe SI, et al. Concentrations and compositions of organochlorine contaminants in sediments, soils, crustaceans, fishes and birds collected from Lake Tai, Hangzhou Bay and Shanghai city region, China. Environ Pollut 2005a;133:415-29.

Nakata H, Kawazoe M, Arizono K, Abe S, Kitano T, Shimada H, et al. Organochlorine pesticides and polychlorinated biphenyl residues in foodstuffs and human tissues from China: status of contamination, historical trend, and human dietary exposure. Arch Environ Con Tox 2002;43:473-80.

Nakata H, Nasu T, Abe S, Kitano T, Fan QY, Li WH, et al. Organochlorine contaminants in human adipose tissues from China: mass balance approach for estimating historical Chinese exposure to DDTs. Environ Sci Technol 2005b;39:4714-20.

Nonferrous Metals Industry Institute. The Yearbook of Nonferrous Metals Industry of China. Beijing: Nonferrous Metals Industry Institute; 2004.

Pacyna JM, Breivik K, Munch J, Fudala J. European atmospheric emissions of selected persistent organic pollutants, 1970-1995. Atmos Environ 2003;37:119-31.

Ramu K, Kajiwara N, Lam PKS, Jefferson TA, Zhou KY, Tanabe S. Temporal variation and biomagnification of organohalogen compounds in finless porpoises (Neophocaena phocaenoides) from the South China Sea. Environ Pollut 2006;144:516-23.

Ramu K, Kajiwara N, Sudaryanto A, Isobe T, Takahashi S, Subramanian A, et al. Asian mussel watch program: contamination status of polyhrominated diphenyl ethers and organochlorines in coastal waters of Asian countries. Environ Sci Technol 2007;41:4580-6.

Ruan LZ, Zhang YM, Zhao DQ Dong YH, Fasola M. Egretta ga rzetta as a bioindicator of environmental pollution in Tai Lake region (in Chinese). Chin J appl ecol 2003;14:263-8.

SEPA. China's National Implementation Plan for the Stockholm Convention on Persistent Organic Pollutants; 2007.

Shao DD, Shi SX, Zhou L, Huang YR. Atmospheric concentrations of organochlorine pesticides in four provinces along the Yangtze River (in Chinese). Environ Prot 2007a·386:68-9.

Shao DD, Zhou L, Shi SX, Huang YY. Investigation on air levels of organochlorine pesticides in spring and autumn in Beijing (in Chinese). Environ Chem 2007b;26:110-1.

Shi SX, Shao DD, Zhou L. Study on residues of organochloride pesticides in soils of Anhui Province (in Chinese). Acta Sci Circ 2007a;27:1534-41.

Shi SX, Zhou L, Shao DD, Huang YR. Studies on residues of organochloride pesticide POPs in the Soils in Beijing Area (in Chinese). Res Environ Sci 2007b;20:25-9.

Sun JH, Wang GL, Zhang G, Li J, Chai Y, Wang JZ, et al. Distribution of organochlorine pesticides in surface sediments from the middle and lower reaches of the Yellow River (in Chinese). Environ Sci 2007;28:1332-7.

Sun SJ, Zhao JH, Koga M, Ma YX, Liu DW, Nakamura M, et al. Persistent organic pollutants in human milk in women from urban and rural areas in northern China. Environ Res 2005;99:285-93.

Tanabe S, Kunisue T. Persistent organic pollutants in human breast milk from Asian countries. Environ Pollut 2007;146:400-13.

Tremolada P, Calamari D, Gaggi C, Bacci E. Fingerprints of some chlorinated hydrocarbons in plant foliage from Africa. Chemosphere 1993;27:2235-52.

Ueno D, Takahashi S, Tanaka H, Subramanian AN, Fillmann G, Nakata H, et al. Global pollution monitoring of PCBs and organochlorine pesticides using skipjack tuna as a bioindicator. Arch Environ Con Tox 2003;45:378-89.
USEPA. 1990 Emissions inventory of section 112 (c) (6) pollutants: polycyclic organic matter (POM), TCDD, TCDF, PCBs, Hexachlorobenzene, mercury and alkylated lead. Final Report; 1998.

Valle MD, Jurado E, Dachs J, Sweetman AJ, Jones KC. The maximum reservoir capacity of soils for persistent organic pollutants: implications for global cycling. Environ Pollut 2005;134:153-64.

Waliszewski SM, Aguirre AA, Infanzon RM. Levels of organochlorine pesticides in blood serum and umbilical blood serum of mothers living in Veracruz, Mexico. Fresen Environ Bull 1999;8:171-8.

Wan DJ, Jia XS. Characterization and distribution of polychlorinated organic pollutants in soils with some areas of Pearl River Delta as an example (in Chinese). Acta Sci Circ 2005;25:1078-84.

Wan Y, Wei QW, Hu JY, Jin XH, Zhang ZB, Zhen HJ, et al. Levels, tissue distribution, and agerelated accumulation of synthetic musk fragrances in Chinese sturgeon (Acipenser sinensis): comparison to organochlorines. Environ Sci Technol 2007;41:424-30.

Wang ZJ, Lv YB, Wang Y, Ma M. Assessing the ecological risk of substituted benzenes in Huaihe River, China (in Chinese). Acta Sci Circ 2002;22:300-4.

Wang TY, Lu YL, Zhang H, Shi YJ. Contamination of persistent organic pollutants (POPs) and relevant management in China. Environ Int 2005a;31:813-21.

Wang JP, Sun W, Fu Y. Trace perchlorobenzene in chlorothalonil determined by high eficiency liquid phase chromatography (in Chinese). China Chlor-Alkali; 2005b. p. 27-9.

Wang F, Bian YR, Jiang X, Gao HJ, Yu GF, Deng JC. Residual characteristics of organochlorine pesticides in Lou soils with different fertilization modes. Pedosphere 2006;16:161-8.

Wang F, Jiang X, Bian YR, Yao FX, Gao HJ, Yu GF, et al. Organochlorine pesticides in soils under different land usage in the Taihu Lake region, China (in Chinese). J Environ Sci-China 2007a;19:584-90.

Wang J, Guo LL, Li J, Zhang G, Lee CSL, Li XD, et al. Passive air sampling of DDT, chlordane and HCB in the Pearl River Delta, South China: implications to regional sources. J Environ Monit 2007b;9:582-8.

Wang LL, Wang L, Lu XH. Multi-medium environmental distribution of HCB discharged from a chemical plant. Environ Sci Technol 2007c;30:5-9 (in Chinese).

Wang XP, Yao TD, Cong ZY, Yan XL, Kang SC, Zhang Y. Distribution of persistent organic pollutants in soil and grasses around Mt. Qomolangma, China. Arch Environ Con Tox 2007d;52:153-62

Wang YW, Zhang QH, Lv JX, Li A, Liu HX, Li GG, et al. Polybrominated diphenyl ethers and organochlorine pesticides in sewage sludge of wastewater treatment plants in China. Chemosphere 2007e;68:1683-91.

Wei TL, Jia XS, Du QP. Chlorobenzenes in the waters, sediments and aquatic animals from the Pearl River Estuary (in Chinese). Acta Sci Circ 2007a;27:1717-26.

Wei DB, Kameya T, Urano K. Environmental management of pesticidal POPs in China: past, present and future. Environ Int 2007b;33:894-902.

Wei S, Lau RKF, Fung CN, Zheng GJ, Lam JCW, Connell DW, et al. Trace organic contamination in biota collected from the Pearl River Estuary, China: a preliminary risk assessment. Mar Pollut Bull 2006;52:1682-94.

Wei S, Wang Y, Lam JCW, Zheng GJ, So MK, Yueng LWY, et al. Historical trends of organic pollutants in sediment cores from Hong Kong. Mar Pollut Bull 2008;57:758-66.

Westberg HB, Selden AI, Bellander T. Emissions of some organochlorine compounds in experimental aluminum degassing with hexachloroethane. Appl Occup Environ Hyg 1997;12:178-83.

Wu WZ, Schramm KW, Henkelmann B, Xu Y, Yediler A, Kettrup A. PCDD/F-s, PCBs, HCHs and HCB in sediments and soils of Ya-Er lake area in China: results on residual levels and correlation to the organic carbon and particle size. Chemosphere 1997;34:191-202.

Xu DD, Deng LL, Chai ZF, Mao XY. Organohalogenated compounds in pine needles from Beijing city, China. Chemosphere 2004a;57:1343-53.

Xu DD, Zhong WK, Deng LL, Chai ZF, Mao XY. Regional distribution of organochlorinated pesticides in pine needles and its indication for socioeconomic development. Chemosphere 2004b;54:743-52.

Xue ND, Xu XB, Jin ZL. Screening 31 endocrine-disrupting pesticides in water and surface sediment samples from Beijing Guanting reservoir. Chemosphere 2005;61:1594-606

Yang NQ Matsuda M, Kawano M, Wakimoto T. PCBs and organochlorine pesticides (OCPs) in edible fish and shellfish from China. Chemosphere 2006;63:1342-52.

Yang JM, Wang Y, Su QQ. Investigation of organochlorine pesticides residue in Wuhan section of the Yangtze River (in Chinese). J Wuhan Inst Chem Tech 2004;26:38-41.

Yang RQ Yao TD, Xu BQ, Jiang GB, Zheng XY. Distribution of organochlorine pesticides (OCPs) in conifer needles in the southeast Tibetan Plateau. Environ Pollut 2008;153:92-100.

Yu HF, Zhao XD, Zhang XM, Zhu ZQ, Zhao Z. The investigation on basic contents of organochlorine pesticides in human milk during consecutive periods in Beijing urban areas (in Chinese). Chin J Prev Med 2005a;39:22-5.

Yu HF, Zhao XD, Zhang XM, Zhu ZQ, Zhao Z. The investigation on basic contents of organochlorine pesticides in human milk during consecutive periods in Beijing urban areas (in Chinese). Chin J Prev Med 2005b;39:22-5.

Yuan XY, Wang Y, Chen J, Sun C, Xu NZ. Organochlorine residues of sediments in Taihu Lake and its risk evaluation (in Chinese). Environ Sci 2003;24:121-5.

Zhang HB, Luo YM, Zhao QG, Wong MH, Zhang GL. Residues of organochlorine pesticides in Hong Kong soils. Chemosphere 2006;63:633-41.

Zhao GF, Xu Y, Li W, Han GG, Li B. PCBs and OCPs in human milk and selected foods from Luqiao and Pingqiao in Zhejiang, China. Sci Total Environ 2007;378:281-92.

Zhou X, Yu G, Huang J, Zhang ZL, Hu HY. Residues and distribution characters of chlorobenzenes in soil and plants from Beijing aoutheast chemical Industry zone (in Chinese). Environ Sci 2007;28:249-54.

Zhou X, Yu G, Zhang ZL, Niu JF. Chlorobenzenes in water and surface sediments from Tonghui River of Beijing (in Chinese). Environ Sci 2005;26:117-20. 